\title{
Effects of the Dietary Tryptophan and Aspartate on the Immune Response of Meagre (Argyrosomus regius) after Stress
}

\author{
Daniel Gonzalez-Silvera ${ }^{1}$ (D), Marcelino Herrera ${ }^{2}$, Inmaculada Giráldez ${ }^{3}$ and \\ María Ángeles Esteban $1, *$ (1) \\ 1 Fish Innate Immune System Group, Department of Cell Biology and Histology, Faculty of Biology, \\ Campus Regional de Excelencia Internacional “Campus Mare Nostrum”, University of Murcia, \\ 30100 Murcia, Spain; danielgs@um.es \\ 2 Instituto de Investigación y Formación Agraria y Pesquera (IFAPA), Agua del Pino, \\ Carretera El Rompido Punta Umbría, Cartaya, 21450 Huelva, Spain; marcelino.herrera@juntadeandalucia.es \\ 3 Faculty of Experimental Sciences, University of Huelva, 21071 Huelva, Spain; giraldez@uhu.es \\ * Correspondence: aesteban@um.es; Tel.: +34-868-887665
}

Received: 30 November 2017; Accepted: 17 January 2018; Published: 24 January 2018

\begin{abstract}
Stress is one of the main problems of farmed fish, where it has been seen to result in a variety of disorders and negative effects. It is considered very important to minimize such effects and one option is the use of dietary additives. In the present experiment, meagre (Argyrosomus regius) specimens were fed three different diets: a control diet consisting of a commercial feed, a tryptophan-supplemented diet and an aspartate-supplemented diet. For each diet, fish were divided into three subgroups: non-stressed (resting), exposed to crowding or air-exposed. Just before the stress, and one and six hours post-stress, serum samples were taken to study several immune parameters (protease, antiprotease, peroxidase and lysozyme) and the bactericidal activity against three fish-pathogenic bacteria (Vibrio angillarum, V. harveyi and Photobacterium damselae subsp. piscicida). The results demonstrated that feeding the animals with the supplemented diets modulates the seric immune parameters, particularly when animals were stressed by air exposure.
\end{abstract}

Keywords: amino acids; functional diet; stress; immunity; serum; meagre (Argyrosomus regius); aquaculture

\section{Introduction}

In fish aquaculture, many environmental stressors may occur; for example, handling, transportation or the movement of fish cages, confinement, poor water quality, poor social and physical environment and disease [1]. For these main reasons, it is considered of priority importance to study the response of fish to such stressors and, at the same time, to diminish the negative effects of the stress on farmed fish. Reducing the negative effects of stress on animals will improve welfare and health. Farmers know that that is a key factor for maintaining fish without stress and in a perfect equilibrium with the aquatic medium [2]. The stress response is the normal reaction of animals to a real or perceived threat, the purpose of which is to maintain or re-establish normal balance or homeostasis [3]. When homeostasis is altered by a stressor, a varied array of neuronal, endocrine, and autonomic response mechanisms can be used to restore homeostasis. This process of "changing to stay the same" is known as allostasis [4]. When stressed, fish launch an endocrine stress response through the activation of the hypothalamic-pituitary-interrenal (HPI) axis to release cortisol into the blood. Cortisol is the main glucocorticoid in fish and the hormone most directly associated with stress. Furthermore, at present it has also been correlated with fish welfare [5]. Indeed, stress levels are 
usually analyzed in relation to basal and post-stress cortisol levels, although some teleost species have a low cortisol response to stress, as in the case of meagre (A. regius, Asso 1801) [6].

Proteins are crucial ingredients of fish diets and supply amino acids for energy, growth, and protein synthesis and as substrates for key metabolic pathways. After the finding that some amino acids and their metabolites are involved in cell signaling, protein kinases, G protein-coupled receptors, and gaseous molecules, there is a growing interest in the study of their implications in varied functions [7]. More concretely, the effects of amino acids on biochemistry, physiology and nutrition started to be analyzed in growth, health and disease of humans and other animals. Besides this, nutritional studies have shown that dietary supplementation with several amino acids (called functional amino acids) regulates key metabolic pathways to improve survival, development, growth, health, welfare and reproduction of the organisms (reviewed by [8]).

Some of the beneficial effects enumerated above as well as increased resistance to environmental stressors and pathogenic organisms have also been demonstrated when amino acids were administered to several fish species [9]. In this regard, the most studied amino acids have been arginine, glutamine, glutamate, tryptophan, sulfur amino acids (methionine, cysteine and taurine) and histidine [8]. In the present work, the attention was focused on two of these amino acids, tryptophan (Trp, the most studied functional amino acids) and aspartate (Asp, non-studied) which is likely to have an anti-stress and immune response modulator effect, as regards the results obtained in chickens [10], although this aspect has hardly been studied in fish. The amino acid L-tryptophan (which is essential in fish) is the only precursor of serotonin, a neurotransmitter that plays a key role in reducing stress and aggression. Serotonin acts through the HPI axis, which controls osmoregulatory, hematological, immunological and behavioral responses. It has been shown that supplementation of the feed with small amounts of Trp causes a reduction in stress in various cultivated species and improves their immune response [11]. It has been demonstrated that exogenous tryptophan decreases cannibalism, increases survival and improves growth in several fish species [12,13].

The meagre is a fish species whose cultivation is experiencing a "boom" at present in Spain, since its production was virtually non-existent in the year 2000 and reached 1642 tons in 2015 [14]. There are still few data with respect to diseases of this species. It seems that meagre is quite resistant to the bacterial diseases experienced by other marine fish species. However, there have been cases of parasitism (such as Amyloodinium sp.) [15]. Furthermore, there are no data in the bibliography related to the meagre immunity, in particular to its response to stress events. Therefore, the aim of the present study was to investigate the effect of the dietary administration of feed supplemented with the amino acids Trp or Asp on the humoral systemic immune response of meagre specimens resting (non-stressed) or stressed by crowding or air-exposure. We study and discuss whether the administration of dietary amino acids has any positive effects on mitigating the negative effects of stress on humoral immunity.

\section{Results and Discussion}

Stressors affect fish in all stages of their lives and the stress-specific responses that occur at the biochemical and physiological levels affect the overall health and longevity of the fish. The use of a balanced diet or functional ingredients in diets is thought to substantially reduce the negative effects caused by different stressors on host organisms and have direct effects on individual health [16]. To confirm this in meagre the fish diet was supplemented by using two amino acids (Trp or Asp). On the other hand, the stressors assayed in this work were two very frequently found in the actual aquaculture practices: air exposure and crowding. We selected those amino acids because they were traditionally classified as nutritionally essential or non-essential for mammals, birds and fish based on nitrogen balance or growth. However, now, conventional definitions on essential and non-essential amino acids for fish are challenged by numerous discoveries that taurine, glutamine, glycine, proline and hydroxyproline promote growth, development, and health of aquatic animals. Functional amino acids could be used to design balanced aquafeeds to enhance the efficiency and profitability of global 
aquaculture production [9]. Furthermore, we tested the same dosages and administration time that those used previously in other fish species [17-22].

The innate immune system of vertebrates has numerous mechanisms to control endogenous and exogenous bacteria and thus prevent infection by these microorganisms. These mechanisms range from physical barriers (such as the skin, scales or mucosal epithelium) to a highly sophisticated array of molecules and cells that function to suppress or prevent microbial infection [23]. The effects of amino acids on fish immune system have been studied in some fish species of interest in aquaculture practices such as European sea bass and salmonids. For example, it has been demonstrated that European sea bass immune status and disease resistance were impaired when fed Arg-supplemented diets (1\% and $2 \%$ ) [24]. Furthermore, methionine has higher effect on the innate immune response to inflammation than Trp [25], while Trp and its metabolites stimulated T-regulatory cells [26].

In the present study, blood samples were obtained to determine the activity of several enzymes related to the immune status in serum, as well as the bactericidal immune activity of meagre specimens fed the different experimental diets and after being stressed. The serum of fish has many and varied enzymes that play important roles in immunity [27]. For the present work, four key enzymes were studied: protease, antiprotease, peroxidase and lysozyme, all of which were present in meagre serum. However, no significant variations were detected in the levels of these enzymes following the incorporation of amino acids in the diet (Figures 1-4). This may be due to the short time that the diets were administered (only 7 days) although other many factors (such as amino acid dose) could also be involved. Another reason could be that the effects of such amino acids are notable on cellular immunity, more than on humoral immunity. This can be deduced from the recent results obtained in vitro on European sea bass leucocytes. The activities of such cells were modulated by the presence of amino acids in the culture medium [26]. Further studies are needed in order to optimize the range of active doses of the amino acids on meagre immunity.

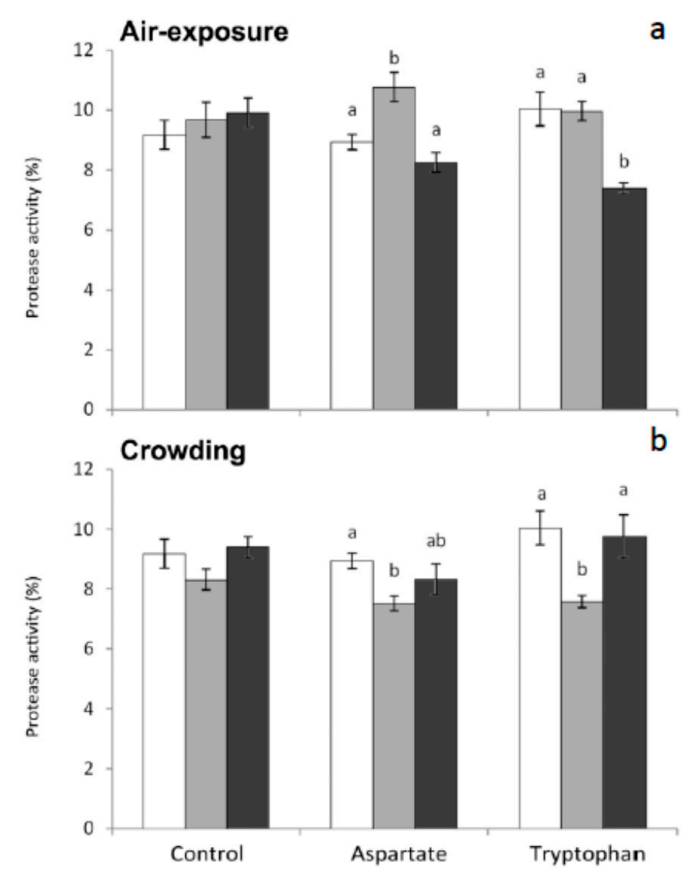

Figure 1. Protease activity (\%) in fish stressed by (a) air-exposure or (b) crowding. Results are shown as mean \pm standard error. Different letters indicate significant differences among non-stressed fish (white bars), $1 \mathrm{~h}$ post stress (grey bars) and $6 \mathrm{~h}$ post stress (black bars). Differences were considered significant when $p<0.05$. 
Proteases are proteins charged with the hydrolysis of peptide bonds, while antiproteases have the capacity to maintain the proteases present in tissues (blood in this work). Antiproteases play crucial roles in the inhibition of the action of proteases either by binding to their active sites or by 'trapping' the protease to prevent protein hydrolysis [28]. These functions restrict the ability of bacteria to invade and grow in fish [29]. Furthermore, it is known that a correct balance between protease and antiprotease activities is needed to safeguard the accurate functionality of any tissue or organ. Besides this, an imbalance of protease and antiprotease activities predispose fish to disease [30]. Many microorganisms (mainly bacteria) express a variety of proteases. Some proteases are non-specific and powerful enzymes that degrade many proteins involved in innate immunity, and others are extremely precise and specific in their mode of action [31]. The importance of having antiproteases in serum in order to neutralize these proteases is evident. In the present work, protease in serum was significantly higher in fish fed the Asp diet and sampled $1 \mathrm{~h}$ after air-exposure, compared to non-stressed fish. Contrarily, protease activity decreased significantly in those fish fed Trp diet and sampled $6 \mathrm{~h}$ after air-exposure (Figure 1). Furthermore, statistically significant decreases were obtained in protease activity of fish fed both Asp and Trp diets and sampled $1 \mathrm{~h}$ post crowding, compared to non-stressed fish (Figure 1).

Antiprotease activity decreased in fish fed the control diets and sampled $1 \mathrm{~h}$ or $6 \mathrm{~h}$ after air-exposure or crowding, respectively, with respect to non-stressed fish (Figure 2). The supplementation of diets with Asp o Trp resulted in a lack of significant differences for antiprotease activity among the three diets assayed. This finding supports the idea that these amino acids improve the fish health by maintaining the levels of this enzyme under the two stress conditions assayed. It has been demonstrated that dietary supplementation with Trp suppress the neuroendocrine stress response in vertebrates including teleosts. Further researches are needed to understand the complex relationships between neuroendocrine and immune factors in fish.

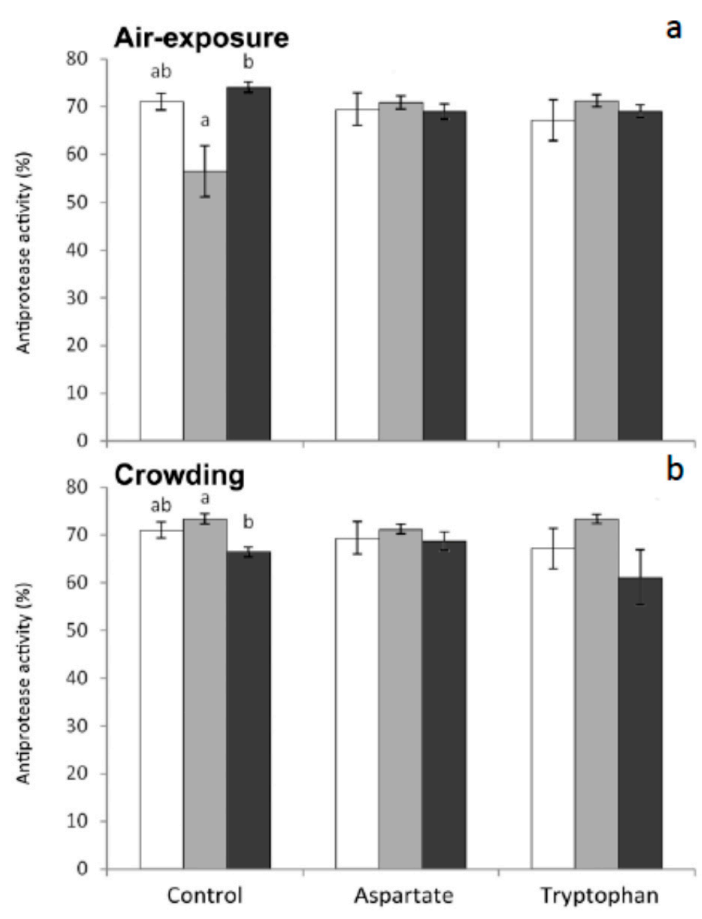

Figure 2. Antiprotease activity (\%) in fish stressed by (a) air-exposure or (b) crowding. Results are shown as mean \pm standard error. Different letters indicate significant differences among non-stressed fish (white bars), $1 \mathrm{~h}$ post stress (grey bars) and $6 \mathrm{~h}$ post stress (black bars). Differences were considered significant when $p<0.05$. 
Peroxidase is an important enzyme that catalyzes the anion superoxide to produce chloride acid. This anion can be produced by other immune defense pathways, such as respiratory burst [32]. Furthermore, peroxidase has microbicidal properties because it uses one of the oxidative radicals $\left(\mathrm{H}_{2} \mathrm{O}_{2}\right)$ to produce hypochlorous acid, in a process that is very important as a way of killing foreign microorganisms [33]. In the present work, statistically significant decreases were observed in the serum from fish fed the control diet and sampled $6 \mathrm{~h}$ after air-exposure, with respect to non-stressed fish. No significant variations were recorded in this activity for any other group of fish tested in the present work (Figure 3). These results seem to indicate that feeding meagre with diets supplemented with amino acids as a preventive treatment could lessen or avoid the decreases of seric peroxidase caused by air-exposure.

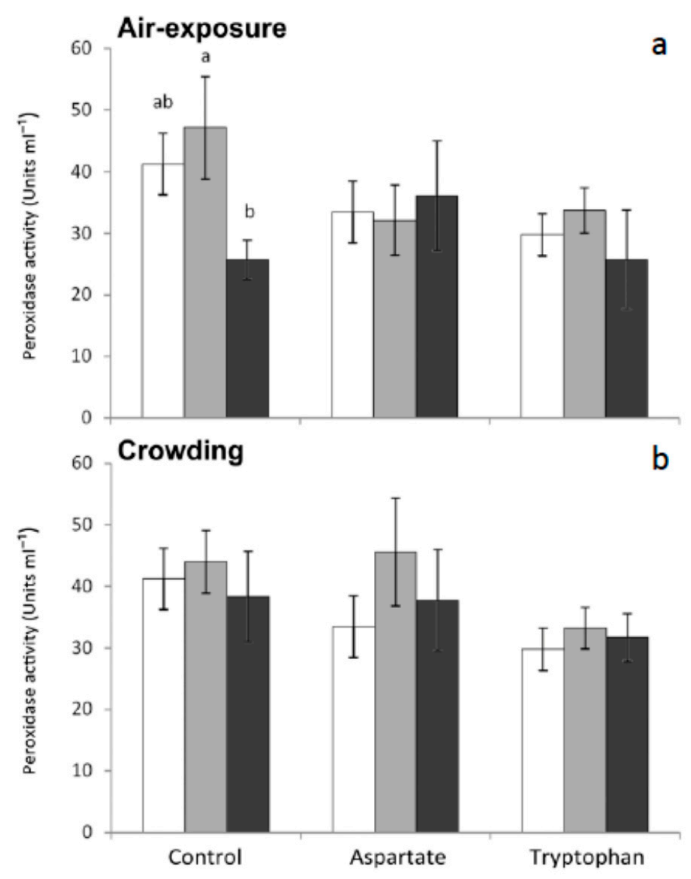

Figure 3. Peroxidase activity (units $\mathrm{mL}^{-1}$ ) in fish stressed by (a) air-exposure or (b) crowding. Results are shown as mean \pm standard error. Different letters indicate significant differences among non-stressed fish (white bars), $1 \mathrm{~h}$ post stress (grey bars) and $6 \mathrm{~h}$ post stress (black bars). Differences were considered significant when $p<0.05$.

Lysozyme (1,4- $\beta-N$-acetylmuramidase) levels are widely considered an important index of innate immunity of fish. Lysozyme is a very important enzyme involved in the prevention of bacterial infections, since it attacks the peptidoglycan present in certain bacterial cell walls with lytic action. It is also known to be opsonic in nature and activates the complement system and phagocytes [34]. No significant variations were recorded in this activity for any group of fish tested in the present work. In other words, supplementation of the diet with amino acids and subsequent exposure to stress by air exposure or crowding have no effect on seric lysozyme levels of meagre (Figure 4). Further research is needed to understand the reasons of the stability of lysozyme levels in meagre serum after being stressed. 


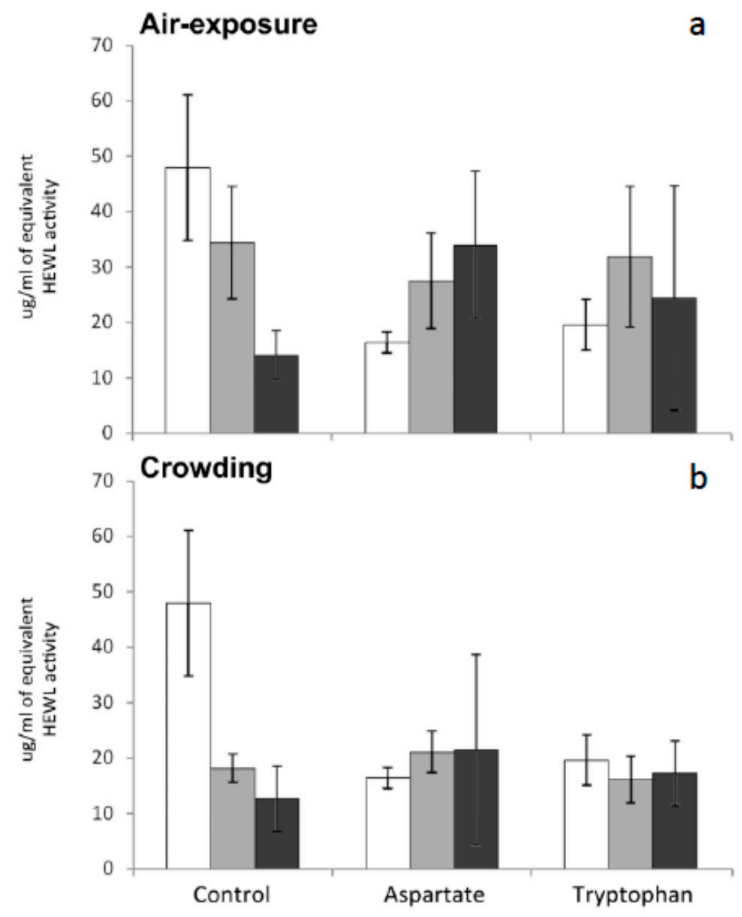

Figure 4. Lysozyme activity ( $\mu \mathrm{g} \mathrm{mL}^{-1}$ of equivalent hen egg white lysozyme activity) in fish stressed by (a) air-exposure or (b) crowding. Results are shown as mean \pm standard error. Non-stressed fish (white bars), $1 \mathrm{~h}$ post stress (grey bars) and $6 \mathrm{~h}$ post stress (black bars). Differences were considered significant when $p<0.05$.

In a previous study, our team evaluated the same enzymes as tested in the present work, using the same methodologies in serum of gilthead seabream (S. aurata L.), one of the main fish species in marine aquaculture [35]. Higher protease activity was found in serum from gilthead seabream but lower antiprotease, peroxidase and lysozyme activity than the levels recorded in the serum from meagre. The most pronounced differences were seen in the levels of antiprotease (70 vs. 4 in percentage) and peroxidase ( $40 \mathrm{vs.} 2$ in units $\left.\mathrm{mL}^{-1}\right)$ in meagre and gilthead seabream, respectively. The values of lysozyme present in serum of both species were more similar. The present results contribute to establishing what should be considered the normal values in the serum of meagre, a fish with a promising future as farmed fish species.

Finally, regarding the bactericidal activity measured in meagre serum, no significant variations were obtained in the bactericidal activity of fish fed the different supplemented diets and in those fish stressed by crowding (Figures 5-7). The bactericidal activity against $V$. anguillarum increased and then decreased in fish fed Asp diet and sampled $1 \mathrm{~h}$ and $6 \mathrm{~h}$ after air exposure, respectively. The differences were statistically significant for fish sampled $6 \mathrm{~h}$ after air exposure, with respect to the values obtained in serum from fish fed the control diet. No significant variations were recorded in the bactericidal activity against this bacterium in fish fed any of the diets and exposed to crowding (Figure 5).

Regarding bactericidal activity against $V$. harveyi, significant decreases were only obtained in serum from fish fed control diet and sampled $6 \mathrm{~h}$ after crowding (Figure 6). No significant variations were recorded in the bactericidal activity against this bacterium in fish fed the different diets and exposed to air (Figure 6). 


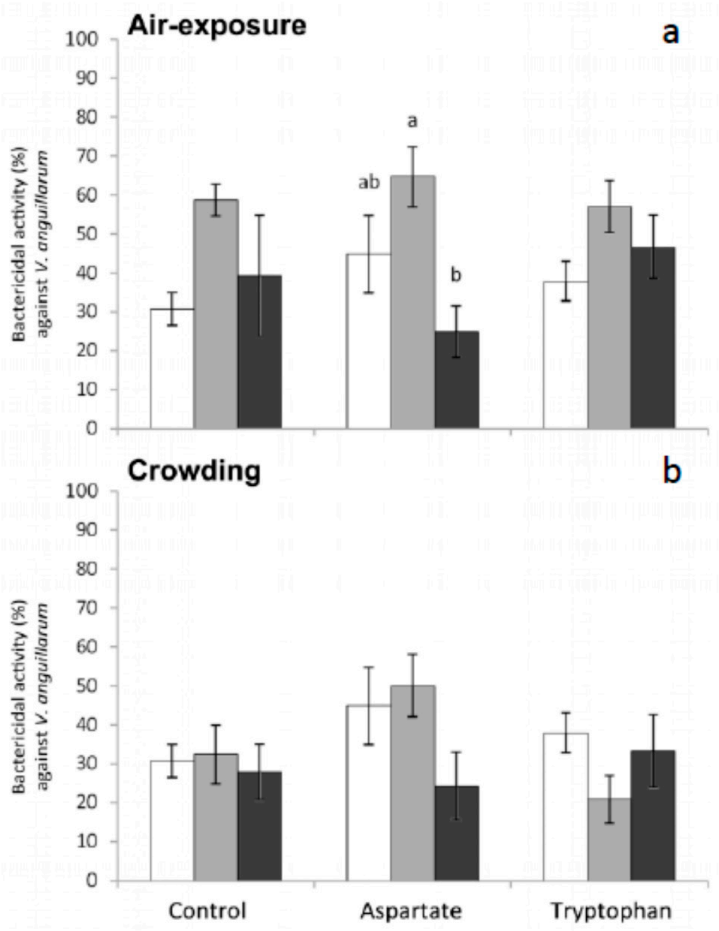

Figure 5. Bactericidal activity (\%) against $V$. anguillarum in fish stressed by (a) air-exposure or (b) crowding. Results are shown as mean \pm standard error. Different letters indicate significant differences among non-stressed fish (white bars), $1 \mathrm{~h}$ post stress (grey bars) and $6 \mathrm{~h}$ post stress (black bars). Differences were considered significant when $p<0.05$.

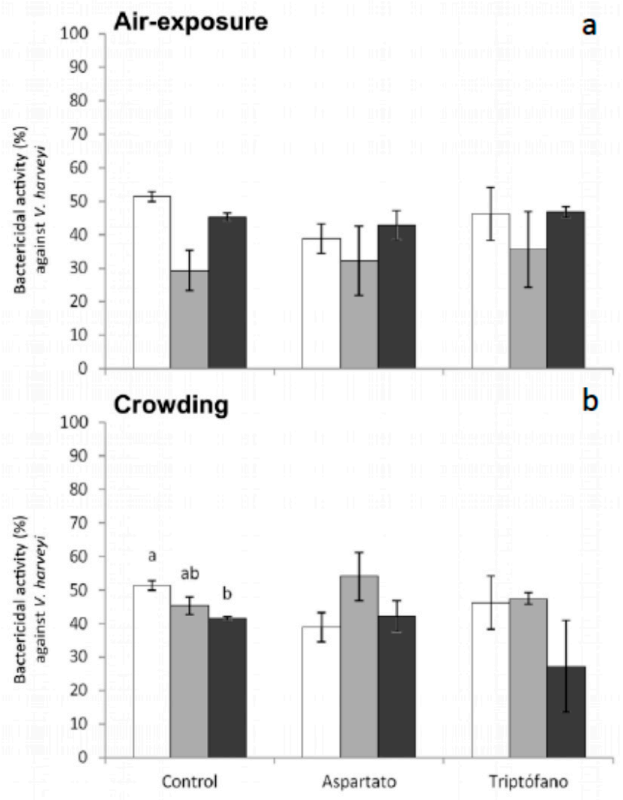

Figure 6. Bactericidal activity (\%) against $V$. harveyi in fish stressed by (a) air-exposure or (b) crowding. Results are shown as mean \pm standard error. Different letters indicate significant differences among non-stressed fish (white bars), $1 \mathrm{~h}$ post stress (grey bars) and $6 \mathrm{~h}$ post stress (black bars). Differences were considered significant when $p<0.05$.

Finally, regarding bactericidal activity against $P$. damselae, no significant variations were obtained in fish fed the different experimental diets and stressed by crowding although substantial differences 
were observed in the fish stressed by air exposure (Figure 7). More specifically, this activity increased in fish fed the control diet and the Trp diet and sampled $1 \mathrm{~h}$ after air exposure (Figure 7).

Serum bactericidal activity is a mechanism known for the killing and clearing of pathogenic organisms in fish [36]. For the present work, three pathogenic bacteria for other marine teleosts (obtained from infected gilthead seabream (Sparus aurata L.) specimens were selected. As previously mentioned, the studied enzymes in meagre serum are all involved in this important activity against bacteria, which are the main causes of diseases in farmed fish. The most noticeable differences in the serum samples from the fish studied in the present work were detected for protease and antiprotease levels, while peroxidase and lysozyme levels were more stable. On the other hand, air exposure had more impact than crowding on the seric enzymes studied. More studies are needed to understand all the beneficial properties of fish diets enriched with amino acids in order to reinforce fish immune status.

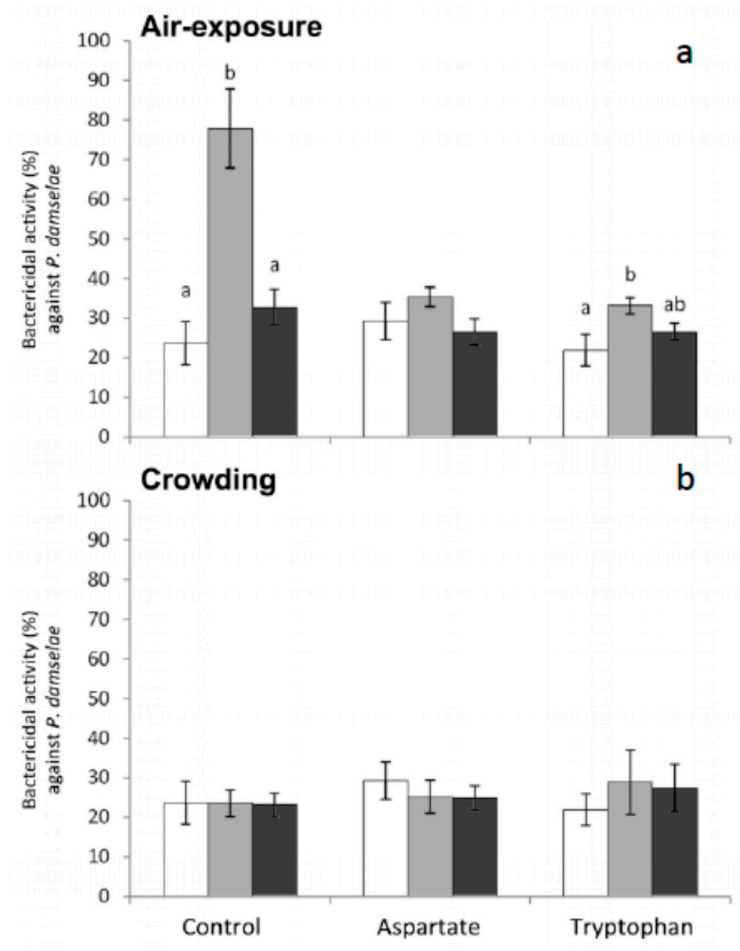

Figure 7. Bactericidal activity (\%) against $P$. damselae in fish stressed by (a) air-exposure or (b) crowding. Results are shown as mean \pm standard error. Different letters indicate significant differences among non-stressed fish (white bars), $1 \mathrm{~h}$ post stress (grey bars) and $6 \mathrm{~h}$ post stress (black bars). Differences were considered significant when $p<0.05$.

\section{Materials and Methods}

\subsection{Diets Preparation}

Commercial fish feed (Skretting, Burgos, Spain) was used as the control diet. L-tryptophan (dry powder) was purchased from Sigma-Aldrich (St. Louis, MO, USA). The commercial control diet was finely ground and then mixed with water $\left(400 \mathrm{~mL} \mathrm{~kg}^{-1}\right.$ dry feed) and Trp or Asp supplementations. The amount of amino acid added was 1\% (dry weight). The mixture was thread pelleted into $2 \mathrm{~mm}$ diameter and $20-25 \mathrm{~cm}$ length strips. These food strips were dried at $60^{\circ} \mathrm{C}$ for $24 \mathrm{~h}$. Finally, these were cut to get $2-3 \mathrm{~mm}$ size pellets, which were stored at $4{ }^{\circ} \mathrm{C}$.

All experimental diets were later analyzed through gas chromatography-mass spectrometry (GC-MS) to determine the final amino acid content. Feed homogenization was done through basic hydrolysis as reported in [37]. For derivatization, an aliquot $(100 \mu \mathrm{L})$ of standard solution or sample was placed in a $2-\mathrm{mL}$ vial, adding $400 \mu \mathrm{L}$ of a water/ethanol/pyridine (60:32:8) mixtureand $40 \mu \mathrm{L}$ of 
ethyl chloroformate. It was capped and vigorously shaken a vortex mixer for $30 \mathrm{~s}$ at room temperature. Then, $200 \mu \mathrm{L}$ of chloroform (containing 1\% elemental choline free) was added and the derivatives were extracted into the organic phase by striking the tube against a pad for about $30 \mathrm{~s}$. The organic phase was dried with anhydrous sodium sulfate. The organic layer was transferred into a new vial with a $300-\mu \mathrm{L}$ fixed insert. Aliquots $(1 \mu \mathrm{L})$ of the derived extracts were injected into a Shimadzu GC-MS (GCMS-TQ8030, Duisburg, Germany) equipped with an Agilent HP-5MS fused silica capillary column (30-m × 0.25-mm i.d., 0.25-mm film thickness, Shimadzu, Duisburg, Germany). The gas chromatograph system was equipped with a split/splitless injection port operating in splitless mode. The oven temperature was programmed from $40{ }^{\circ} \mathrm{C}(5 \mathrm{~min})$ to $270{ }^{\circ} \mathrm{C}(20 \mathrm{~min})$ by increasing the temperature at $5{ }^{\circ} \mathrm{C} \mathrm{min}^{-1}$. The transfer line was heated at $280^{\circ} \mathrm{C}$. The carrier gas was helium with a constant flow of $1 \mathrm{~mL} \mathrm{~min} \mathrm{~min}^{-1}$ (mean velocity $36 \mathrm{~cm} \mathrm{~s}^{-1}$ ). The mass spectrometer was performed with electron ionization (EI) at $70 \mathrm{eV}$, operating in scan mode (75-500 amu). Identification of derived amino acids was achieved comparing the gas chromatograph retention times and mass spectra with those of the pure standard compounds. All mass spectra were also compared with the data system library (NIST 11) [37]. Quantification of samples was conducted by the external standard method following the same procedure as that for samples.

Experimental feed composition is shown in Table 1.

Table 1. Experimental feed analysis (focused on contents of target amino acids and others). Units in \% on dry food (mean \pm standard deviation (SD); $S D<0.01$ in all values).

\begin{tabular}{cccc}
\hline & Control & Trp & Asp \\
\hline $\begin{array}{c}\text { Crude protein } \\
\text { Crude fat }\end{array}$ & 46.5 & 46.5 & 46.5 \\
& 20 & 20 & 20 \\
\hline Trp & Amino Acid Content \\
Asp & 0.07 & 0.11 & 0.07 \\
Phe & 1.06 & 1.06 & 1.78 \\
Tyr & 0.3 & 0.3 & 0.3 \\
Met & 0.18 & 0.18 & 0.18 \\
Iso & 0.06 & 0.06 & 0.06 \\
Val & 0.04 & 0.04 & 0.04 \\
& 0.31 & 0.31 & 0.31 \\
\hline
\end{tabular}

\subsection{Fish, Experimental Trial and Sampling}

One hundred and fifty meagres (A. regius L., around one-year-old) obtained from the Olhão Fish Farming Pilot Station (EPPO) of the Portuguese Institute of Atmospheric Sea (EPPO-IPMA, Olhão, Portugal) were kept in re-circulating seawater aquarias (600 L) in the IFAPA Centro Agua del Pino (Cartaya, Spain). Fish weight was $105 \pm 2.6 \mathrm{~g}$ (mean \pm standard error, SE). The water temperature was maintained at $19 \pm 1{ }^{\circ} \mathrm{C}$ with a flow rate of $2 \mathrm{~m}^{3} \mathrm{~h}^{-1}$ and $33 \%$ salinity. The photoperiod was natural and fish were fed a commercial pellet diet (Skretting, Burgos, Spain) at a rate of $1 \%$ body weight day ${ }^{-1}$. Fish were allowed to acclimatize for 21 days before the start of the experimental trial.

The experiment complied with the Guidelines of the European Union Council (2010/63/EU) and the Spanish Government (RD1201/2005; RD53/2013 and law 32/2007) for the use of laboratory animals. All experimental protocols were approved by the Ethical Committee of the IFAPA (Andalusian Institute of Researching and Training on Fisheries and Agriculture), sited in Seville (Spain).

The fish were distributed in 6 tanks ( 25 fish/tank) and the experimental design was as follows: fish from 2 tanks received a commercial diet (control group), those from another tank received a diet supplemented with aspartate (Asp group) and fish from the other 2 tanks received a diet supplemented with tryptophan (Trp group). Fish were fed these diets during seven days. Afterwards, for each one 
of the three feeding groups of fish (50\% from each replicated tank), 10 fish were reserved as control (non-stressed), 20 fish were subjected to stress by air exposure for $3 \mathrm{~min}$, and other 20 fish were subjected to stress by confinement and netting, which was obtained by decreasing the water level $(20 \mathrm{~cm}$ ) and fish being chased with a net (without exposing them to the air) for $3 \mathrm{~min}$. This last process was repeated every $10 \mathrm{~min}$ for one hour.

Blood samples were collected at baseline time as well as 1 and $6 \mathrm{~h}$ post-stress, according to [38]. Samples were obtained from the caudal vein with an insulin syringe and were left to clot at $4^{\circ} \mathrm{C}$ for $4 \mathrm{~h}$. The serum was collected after centrifugation $\left(2500 \times \mathrm{g}, 10 \mathrm{~min}, 4{ }^{\circ} \mathrm{C}\right)$ and stored at $-80{ }^{\circ} \mathrm{C}$ till used.

\subsection{Immune Parameters}

The total protein concentration was estimated using the Coomassie Brilliant Blue G-250 method [39] with Bradford reagent (Sigma-Aldrich). Briefly, $5 \mu \mathrm{L}$ of serum were incubated with $250 \mu \mathrm{L}$ of Bradford reagent in flat-bottomed 96-well plates (Nunc), and similar volumes of bovine serum albumin (BSA, Sigma-Aldrich) serial dilutions were used as standard. After incubating for $10 \mathrm{~min}$ at room temperature and darkness, the absorbance was read in a plate reader (BMG, Fluostar Omega, Madrid, Spain) at $550 \mathrm{~nm}$. The total protein concentration was expressed as $\mathrm{mg} \mathrm{mL}^{-1}$.

Protease activity was quantified using the azocasein hydrolysis assay [40]. Briefly, an equal volume of serum was incubated with $100 \mathrm{mM}$ ammonium bicarbonate buffer containing $0.7 \%$ azocasein (Sigma-Aldrich) for $19 \mathrm{~h}$ at $25^{\circ} \mathrm{C}$ in triplicate. The reaction was stopped by adding $4.6 \%$ trichloroacetic acid (TCA, Sigma-Aldrich) and the mixture centrifuged at $13,000 \times g, 5 \mathrm{~min}$ ). The supernatants were transferred to a 96-well plate containing $100 \mu \mathrm{L}$ well ${ }^{-1}$ of $0.5 \mathrm{~N} \mathrm{NaOH}$. Then, the OD was read at $450 \mathrm{~nm}$ using a plate reader. Serum was replaced by trypsin solution $\left(5 \mathrm{mg} \mathrm{mL}^{-1}\right)$ as positive control ( $100 \%$ of protease activity), or by buffer, as negative control ( $0 \%$ activity).

Total antiprotease activity was determined as indicated by the capacity of skin mucus to inhibit trypsin activity [41]. Aliquots of $10 \mu \mathrm{L}$ of serum were incubated with $10 \mu \mathrm{L}$ of standard trypsin solution (5 mg mL ${ }^{-1}$; Sigma-Aldrich) for $10 \mathrm{~min}$ at $25^{\circ} \mathrm{C}$ in Eppendorf tubes in triplicates. Then, $100 \mathrm{mM}$ of ammonium bicarbonate buffer containing $0.7 \%$ azocasein were added, and incubated for $2 \mathrm{~h}$ at $25^{\circ} \mathrm{C}$. The reaction was stopped by the addition of $4.6 \% \mathrm{TCA}$, incubated for $30 \mathrm{~min}$ at $25{ }^{\circ} \mathrm{C}$, and then centrifuged at $13,000 \times g$ for $5 \mathrm{~min}$. The supernatants $(100 \mu \mathrm{L})$ were transferred to a 96 -well plate containing $100 \mu \mathrm{L}$ well ${ }^{-1}$ of $1 \mathrm{~N}$ sodium hydroxide ( $\mathrm{NaOH}$, Sigma-Aldrich). The OD was read at $450 \mathrm{~nm}$ using a plate reader. For a positive (100\%) control, phosphate-buffered saline (PBS) replaced the serum, and for a negative control, PBS replaced both skin mucus and trypsin. The antiprotease activity was expressed in terms of percentage of trypsin inhibition according to the formula: \% Trypsin inhibition $=$ Trypsin OD - Sample OD/Trypsin OD $\times 100$.

Peroxidase activity in serum was measured according to Quade and Roth [42] with some modifications. Thus, serum samples were dissolved 1:4 in Hank's balanced salt solution (HBSS) without $\mathrm{Ca}^{+2}$ or $\mathrm{Mg}^{+2}$ in triplicates and dispensed into flat-bottomed 96-well plates. Then, $20 \mathrm{mM}$ 3,3',5,5'-tetramethylbenzidine (TMB; Sigma-Aldrich) and $5 \mathrm{mM} \mathrm{H}_{2} \mathrm{O}_{2}$ were added. The color-change reaction was stopped after $2 \mathrm{~min}$ by adding $50 \mu \mathrm{L} 2 \mathrm{M} \mathrm{H}_{2} \mathrm{SO}_{4}$ and the optical density was read at 450 $\mathrm{nm}$ in a plate reader. Standard samples without serum were used as blanks. One unit was defined as the amount producing an absorbance change of 1 and the activity was expressed as units (U) $\mathrm{mg}^{-1}$ serum proteins.

Lysozyme activity was measured according to the turbidimetric method described by Parry et al. [43] with some modifications. Equal volumes of serum samples and PBS (pH 6.2) were placed in flat-bottomed 96-well plates in triplicate. To each well, $100 \mu \mathrm{L}$ of freeze-dried Micrococcus lysodeikticus (0.3 $\mathrm{mg} \mathrm{mL}^{-1}$, Sigma, Cream Ridge, NJ, USA) was added as lysozyme substrate. The reduction in absorbance at $450 \mathrm{~nm}$ was measured after 0 and $15 \mathrm{~min}$ at $22{ }^{\circ} \mathrm{C}$ in the plate reader. One unit of lysozyme activity was defined as a reduction in absorbance of $0.001 \mathrm{~min}^{-1}$. The units of lysozyme present in serum were obtained from a standard curve made with hen egg white lysozyme (HEWL, Roche, Basel, Switzerland) and the results expressed as $\mathrm{U} \mathrm{mg}^{-1}$ seric proteins. 
Three pathogenic bacteria for marine fish (Vibrio harveyi, Vibrio anguillarum and Photobacterium damselae) were used in the bactericidal assay. All bacterial strains were grown from $1 \mathrm{~mL}$ of stock culture that had been previously frozen at $-80^{\circ} \mathrm{C}$. The three bacteria were cultured for $48 \mathrm{~h}$ at $25^{\circ} \mathrm{C}$ in Triptic Soy Agar (TSA, Difco Laboratories, Franklin Lakes, NJ, USA), and then inoculated in Triptic Soy Broth (TSB, Difco Laboratories), both supplemented with $\mathrm{NaCl}$ to a final concentration of $1 \%(w / v)$. Bacteria in TSB medium were then cultured at the same temperature, with continuous shaking $(100 \mathrm{rpm})$ during $24 \mathrm{~h}$. Exponentially growing bacteria were resuspended in sterile PBS and adjusted to $10^{8}$ colony forming units (c.f.u.) $\mathrm{mL}^{-1}$.

Bactericidal activity was determined following the method of Stevens et al. [44] with some modifications. Samples of $20 \mu \mathrm{L}$ of serum were added in replicates wells of a flat-bottomed 96-well plate. PBS solution was added to some wells instead of the serum and served as positive control. Aliquots of $20 \mu \mathrm{L}$ of the bacteria previously cultured were added and the plates were incubated for $5 \mathrm{~h}$ at $25{ }^{\circ} \mathrm{C}$. After that, $25 \mu \mathrm{L}$ of MTT $\left(1 \mathrm{mg} \mathrm{mL}^{-1}\right)$ were added to each well and the plates were newly incubated for $10 \mathrm{~min}$ at $25^{\circ} \mathrm{C}$ to allow the formation of formazan. Plates were then centrifuged (2000 g, $10 \mathrm{~min}$ ), being the precipitates dissolved in $200 \mu \mathrm{L}$ of dimethyl sulphoxide (DMSO) and transferred to a flat-bottom 96-wellplate. The absorbance of the dissolved formazan was measured at $570 \mathrm{~nm}$. Bactericidal activity was expressed as percentage of no viable bacteria, calculated as the difference between absorbance of bacteria surviving compared to the absorbance of bacteria from positive controls (100\%).

\subsection{Statistical Analysis}

The results are expressed as mean \pm standard error of the mean (SEM). Data were statistically analyzed by one-way analysis of variance (ANOVA). Depending on the homogeneity of variances, Tukey or Games-Howell post-hoc test were carried out to determine differences among groups. Kruskal-Wallis analysis was carried out when data did not meet the normality assumption. All the statistical analyses were conducted using Statistical Package for Social Science (SPSS for Windows; v19.0, IBM, North Castle, NY, USA) and differences were considered statistically significant when $p<0.05$.

Acknowledgments: This work has been financed through the DIETAPlus project of the National Aquaculture Plan (FEMP funds), corresponding to the year 2016 of the Ministry of Economy and Competitiveness of Spain and the Fundación Séneca de la Región de Murcia (Grupo de Excelencia. Grant No. 19883/GERM/15). M.H. is grateful for INIA-FSE contract. The authors thank the IPMA for the cession of the meagre juveniles.

Author Contributions: M.H. and M.A.E. conceived and designed the experiments; D.G.S. and I.G. performed the experiments; D.G.S., I.G. and M.A.E. analyzed the data; M.H. contributed reagents/materials/analysis tools; M.A.E. wrote the paper; all authors revised the manuscript.

Conflicts of Interest: The authors declare no conflict of interest. The founding sponsors had no role in the design of the study; in the collection, analyses, or interpretation of data; in the writing of the manuscript, and in the decision to publish the results.

\section{References}

1. Bricknell, I.; Dalmo, R.A. The use of immunostimulants in fish larval aquaculture. Fish Shellfish Immunol. 2005, 19, 457-472. [CrossRef] [PubMed]

2. Ashley, P.J. Fish welfare: current issues in aquaculture. Appl. Anim. Behav. Sci. 2007, 104, 199-235. [CrossRef]

3. Barton, B.A. Stress in fishes: A diversity of responses with particular reference to changes in circulating corticosteroids. Integr. Comp. Biol. 2002, 42, 517-525. [CrossRef] [PubMed]

4. Sterling, P.; Eyer, J. Allostasis: A new paradigm to explain arousal pathology. In Handbook of Life Stress, Cognition and Health; Fisher, S., Reason, J., Eds.; John Wiley \& Sons: New York, NY, USA, 1988; pp. 629-649.

5. Ellis, T.; Yildiz, H.Y.; López-Olmeda, J.; Spedicato, M.T.; Tort, L.; Øverli, Ø.; Martins, C.I. Cortisol and finfish welfare. Fish Physiol. Biochem. 2012, 38, 163-188. [CrossRef] [PubMed] 
6. Fanouraki, E.; Mylonas, C.C.; Papandroulakis, N.; Pavlidis, M. Species specificity in the magnitude and duration of the acute stress response in Mediterranean marine fish in culture. Gen. Comp. Endocrinol. 2011, 173, 313-322. [CrossRef] [PubMed]

7. Wu, G. Functional amino acids in nutrition and health. Amino Acids 2013, 45, 407-411. [CrossRef] [PubMed]

8. Andersen, S.M.; Waagbø, R.; Espe, M. Functional amino acids in fish nutrition, health and welfare. Front. Biosci. 2016, 1, 143-169.

9. Li, P.; Mai, K.; Trushenski, J.; Wu, G. New developments in fish amino acid nutrition: Towards functional and environmentally oriented aquafeeds. Amino Acids 2009, 37, 43-53. [CrossRef] [PubMed]

10. Erwan, E.; Chowdhury, V.S.; Nagasawa, M.; Goda, R.; Otsuka, T.; Yasuo, S.; Furuse, M. Central injection of L- and D-aspartate attenuates isolation-induced stress behaviour in chicks possibly through different mechanisms. Eur. J. Pharmacol. 2014, 736, 138-142. [CrossRef] [PubMed]

11. Wen, H.; Jiang, W.; Liu, Y.; Jiang, J.; Li, S.; Tang, L.; Zhang, Y.; Kuang, S.; Zhou, X. Dietary tryptophan modulates intestinal immune response, barrier function, antioxidant status and gene expression of TOR and Nrf2 in young grass carp (Ctenopharyngodon idella). Fish Shellfish Immunol. 2014, 40, 275-287. [CrossRef] [PubMed]

12. Hseu, J.R.; Lu, F.I.; Su, H.M.; Wang, L.S.; Tsai, C.L.; Hwang, P.P. Effect of exogenous tryptophan on cannibalism, survival and growth in juvenile grouper, Epinephelus coioides. Aquaculture 2003, 218, 251-263. [CrossRef]

13. Höglund, E.; Bakke, M.J.; Øverli, Ø.; Winberg, S.; Nilsson, G.E. Suppression of aggressive behaviour in juvenile Atlantic cod (Gadus morhua) by L-tryptophan supplementation. Aquaculture 2005, 249, 525-531. [CrossRef]

14. Observatorio Español de Acuicultura (OESA). Available online: http:/ / www.observatorio-acuicultura.es / sites/default/files/images/adjuntos/libros/acuicultura_en_esp2016.pdf (accessed on 13 June 2017).

15. Stipa, P.; Angelini, M. Aquaculture Management and Conservation Service (FIMA) 2005-2017. Programa de Información de Especies Acuáticas. Available online: http:/ / www.fao.org/fishery/culturedspecies / Argyrosomus_regius/en (accesed on 28 December 2017).

16. Oliva-Teles, A. Nutrition and health of aquaculture fish. J. Fish Dis. 2012, 35, 83-108. [CrossRef] [PubMed]

17. Lepage, O.; Tottmar, O.; Winberg, S. Elevated dietary intake of L-tryptophan counteracts the stress-induced elevation of plasma cortisol in rainbow trout (Oncorhynchus mykiss). J. Exp. Biol. 2002, 205 Pt 23, 3679-3687. [PubMed]

18. Lepage, O.; Vílchez, I.M.; Pottinger, T.G.; Winberg, S. Time-course of the effect of dietary L-tryptophan on plasma cortisol levels in rainbow trout Oncorhynchus mykiss. J. Exp. Biol. 2003, 206 Pt 20, 3589-3599. [CrossRef] [PubMed]

19. Höglund, E.; Sørensen, C.; Bakke, M.J.; Nilsson, G.E.; Overli, O. Attenuation of stress-induced anorexia in brown trout (Salmo trutta) by pre-treatment with dietary L-tryptophan. Br. J. Nutr. 2007, 97, 786-789. [CrossRef] [PubMed]

20. Höglund, E.; Øverli, Ø.; Andersson, M.Å.; Silva, P.; Laursen, D.C.; Moltesen, M.M.; Krogdahl, Å.; Schjolden, J.; Winberg, S.; Vindas, M.A.; et al. Dietary L-tryptophan leaves a lasting impression on the brain and the stress response. Br. J. Nutr. 2017, 117, 1351-1357. [CrossRef] [PubMed]

21. Basic, D.; Krogdahl, A.; Schjolden, J.; Winberg, S.; Marco Vindas, M.A.; Hillestad, M.; Mayer, I.; Skjerve, E.; Höglund, E. Short- and long-term effects of dietary L-tryptophan supplementation on the neuroendocrine stress response in seawater-reared Atlantic salmon (Salmo salar). Aquaculture 2013, 388-391, 8-13. [CrossRef]

22. Herrera, M.; Herves, M.A.; Giráldez, I.; Skar, K.; Mogren, H.; Mortensen, A.; Puvanendran, V. Effects of amino acid supplementations on metabolic and physiological parameters in Atlantic cod (Gadus morhua) under stress. Fish Physiol. Biochem. 2017, 43, 591-602. [CrossRef] [PubMed]

23. Magnadottir, B. Immunological control of fish diseases. Mar. Biotechnol. 2010, 12, 361-379. [CrossRef] [PubMed]

24. Azeredo, R.; Pérez-Sánchez, J.; Sitjà-Bobadilla, A.; Fouz, B.; Tort, L.; Aragão, C.; Oliva-Teles, A.; Costas, B. European sea bass (Dicentrarchus labrax) immune status and disease resistance are impaired by arginine dietary supplementation. PLoS ONE 2015, 10, e0139967. [CrossRef] [PubMed]

25. Machado, M.; Azeredo, R.; Díaz-Rosales, P.; Afonso, A.; Peres, H.; Oliva-Teles, A.; Costas, B. Dietary tryptophan and methionine as modulators of European seabass (Dicentrarchus labrax) immune status and inflammatory response. Fish Shellfish Immunol. 2015, 42, 353-362. [CrossRef] [PubMed] 
26. Azeredo, R.; Machado, M.; Afonso, A.; Fierro-Castro, C.; Reyes-López, F.E.; Tort, L.; Gesto, M.; Conde-Sieira, M.; Míguez, J.M.; Soengas, J.L.; et al. Neuroendocrine and immune responses undertake different fates following tryptophan or methionine dietary treatment: Tales from a teleost model. Front. Immunol. 2017, 8, 1226. [CrossRef] [PubMed]

27. Guardiola, F.A.; Cuesta, A.; Arizcun, M.; Meseguer, J.; Esteban, M.A. Comparative skin mucus and serum humoral defense mechanisms in the teleost gilthead seabream (Sparus aurata). Fish Shellfish Immunol. 2014, 36, 545-551. [CrossRef] [PubMed]

28. Laskowski, M., Jr.; Kato, I. Protein inhibitors of proteinases. Annu. Rev. Biochem. 1980, 49, 593-626. [CrossRef] [PubMed]

29. Agbowuro, A.A.; Huston, W.M.; Gamble, A.B.; Tyndall, J.D.A. Proteases and protease inhibitors in infectious diseases. Med. Res. Rev. 2017. [CrossRef] [PubMed]

30. Greene, C.M.; McElvaney, N.G. Proteases and antiproteases in chronic neutrophilic lung disease-Relevance to drug discovery. Br. J. Pharmacol. 2009, 158, 1048-1058. [CrossRef] [PubMed]

31. Potempa, J.; Pike, R.N. Corruption of innate immunity by bacterial proteases. J. Innate Immun. 2009, 1, 70-87. [CrossRef] [PubMed]

32. Dalmo, R.A.; Ingebrigtsen, K.; Bøgwald, J. Non-specific defense mechanisms in fish, with particular reference to the reticuloendothelial system (RES). J. Fish Dis. 1997, 20, 241-273. [CrossRef]

33. Johnston, R.B., Jr. Oxygen metabolism and the microbicidal activity of macrophages. Fed. Proc. 1978, 37, 2759-2764. [PubMed]

34. Paulsen, S.M.; Lunde, H.; Engstad, R.E.; Robertsen, B. In vivo effects of $\beta$-glucan and LPS on regulation of lysozyme activity and mRNA expression in Atlantic salmon (Salmo salar L.). Fish Shellfish Immunol. 2003, 14, 39-54. [CrossRef] [PubMed]

35. Guardiola, F.A.; Cuesta, A.; Abellán, E.; Meseguer, J.; Esteban, M.A. Comparative analysis of the humoral immunity of skin mucus from several marine teleost fish. Fish Shellfish Immunol. 2014, 40, 24-31. [CrossRef] [PubMed]

36. Dai, Z.; Wu, Z.; Ji, S.; Wu, G. Analysis of amino acid composition in proteins of animal tissues and foods as pre-column o-phthaldialdehyde derivatives by HPLC with fluorescence detection. J. Chromatogr. B 2014, 964, 116-127. [CrossRef] [PubMed]

37. Samaras, A.; Papandroulakis, S.; Costari, M.; Pavlidis, M. Stress and metabolic indicators in a relatively high (European sea bass, Dicentrarchus labrax) and a low (meagre, Argyrosomus regius) cortisol responsive species, in different water temperatures. Aquac. Res. 2016, 47, 3501-3515. [CrossRef]

38. Graham, S.; Jeffries, A.H.; Secombes, C.J. A novel assay to detect macrophage bactericidal activity in fish: Factors influencing the killing of Aeromonas salmonicida. J. Fish Dis. 1988, 11, 389-396. [CrossRef]

39. Bradford, M.M. A rapid and sensitive method for the quantitation microgram quantities of protein utilizing the principle of protein-dye binding. Anal. Biochem. 1976, 72, 248-254. [CrossRef]

40. Ross, N.; Kara, J.; Anping, W.; Burka, J.; Johnson, S. Changes in hydrolytic enzyme activities of naïve Atlantic salmon Salmo salar skin mucus due to infection with the salmon louse Lepeophtheirus salmonis and cortisol implantation. Dis. Aquat. Org. 2000, 41, 43-51. [CrossRef] [PubMed]

41. Hanif, A.; Bakopoulos, V.; Dimitriadis, G.J. Maternal transfer of humoral specific and non-specific immune parameters to sea bream (Sparus aurata) larvae. Fish Shellfish Immunol. 2004, 17, 411-435. [CrossRef] [PubMed]

42. Quade, M.J.; Roth, J.A. A rapid, direct assay to measure degranulation of bovine neutrophil primary granules. Vet. Immunol. Immunopathol. 1997, 58, 239-248. [CrossRef]

43. Parry, R.; Chandan, R.; Shahani, K. A rapid and sensitive assay of muramidase. Proc. Soc. Exp. Biol. Med. 1965, 119, 384-386. [CrossRef] [PubMed]

44. Stevens, M.G.; Kehrli, M.E.; Canning, P.C. A colorimetric assay for quantitating bovine neutrophil bactericidal activity. Vet. Immunol. Immunopathol. 1991, 28, 45-56. [CrossRef]

(C) 2018 by the authors. Licensee MDPI, Basel, Switzerland. This article is an open access article distributed under the terms and conditions of the Creative Commons Attribution (CC BY) license (http:/ / creativecommons.org/licenses/by/4.0/). 